7 Rona RJ. Genetic and environmental factors in the control of growth in childhood. Br Med Bull 1981;37:265-72.

8 Haenzel W. Studies of migrant populations. $\mathcal{F}$ Chronic Dis 1970;23:289-91.

9 Pocock SJ, Shaper AG, Cook DG, et al. British regional heart study: geographic variations in cardiovascular mortality, and the role of water quality. Br Med f 1980:280:1243-9.

10 Shaper AG, Pocock SJ, Walker M, et al. British regional heart study: cardiovascular risk factors in middle-aged men in 24 towns. $\mathrm{Br} \mathrm{Med} \mathcal{f}$ cardiovascular risk

11 Bruce NG, Shaper AG, Walker M, Wannamethee G. Observer bias in blood pressure studies $f$ Hypertens 1988:6:375-80.

2 Office of Population Censuses and Surveys. Mortality statistics: area. England and Wales 1985. London: HMSO, 1987. (Series DH5 No 12.)

3 SAS Institute. SAS user's guide: statistics version 5 edition. Cary, North Carolina: SAS Institute, 198

14 Bentham G. Migration and morbidity; implications for geographical studies of disease. Soc Sci Med 1988;26:49-54.

15 Registrar General, Scotland. Annual report 1985. Edinburgh: HMSO, 1986.
16 Bulpitt CJ. The prognosis of essential hypertension. In: Bulpitt CJ, ect Epidemiology of hypertension. Amsterdam: Elsevier, 1985.

17 Marmot MG. Geography of blood pressure and hypertension. Br Med Bull $1984 ; 40: 380-6$

18 Cassel J. Studies of hypertension in migrants. In: Paul O, ed. Epidemiology and control of hypertension. New York: Stratton, 1975.

19 Elford J, Phillips AN, Thomson AG, Shaper AG. Migration and geographic variations in ischemic heart disease in Great Britain Lancet 1989;:343-6.

20 Shaper AG, Wannamethee G, Whincup PH. Alcohol and blood pressure in middle-aged British men. Fournal of Human Hypertension 1988;2:71-8.

21 Fagard R, M'Buyamba J-R, Staessen J, Vanhees L, Amery A. Physical activity and blood pressure. In: Bulpitt C, ed. Epidemiology of hypertension. Amsterdam: Elsevier, 1985.

22 Pocock SJ, Shaper AG, Cook DG, Phillips AN, Walker M. Social class differences in ischaemic heart disease in British men. Lancet 1987; ;i $197-201$

(Accepted 27 November 1989)

\title{
Examination of fetuses after induced abortion for fetal abnormality
}

\author{
Jill Clayton-Smith, P A Farndon, Carole McKeown, Dian Donnai
}

Abstract

Objective-To determine the accuracy of midtrimester diagnosis of fetal abnormality by examination and investigation of fetuses after induced abortion.

Design-Prospective study over five years of fetuses aborted in the midtrimester because of abnormalities detected by ultrasonography and amniocentesis. Techniques included a full external examination by a clinical geneticist with experience in dysmorphology and other investigations including necropsy.

Setting-Regional genetic centre.

Participants-Clinicians working within the North Western region who wished to use the service offered.

Results-133 Fetuses were aborted because of abnormalities detected on ultrasonography and 115 because of abnormal findings on amniotic fluid analysis. In a further two cases fetal abnormality was diagnosed by molecular genetic and biochemical techniques. Among the fetuses with abnormal scans the pretermination diagnosis was changed or refined in a way which affected genetic counselling in $\mathbf{5 3}$ of 133 cases. Among the 115 fetuses diagnosed as abnormal by amniocentesis the pretermination diagnosis was confirmed in 112 cases and altered in three.

TABLE I-Routine observations on each midtrimester fetus

\begin{tabular}{ll}
\hline \multicolumn{1}{c}{ Fetus } & \multicolumn{1}{c}{ Placenta } \\
\hline Weight & Weight \\
Crown-rump length and crown-heel length & Macroscopic appearance \\
Occipitofrontal circumference & Number of cord vessels \\
Foot length, medial border & Length of cord \\
Inner and outer canthal distance & \\
External sex & \\
External appearance documenting structural & \\
abnormalities & \\
\end{tabular}

BrMed f 1990;300:295-7
Conclusion-Fetuses aborted because of abnormalities detected by screening should be examined by suitably experienced clinicians, both for accurate genetic counselling of the families and for quality control of the tests employed.

\section{Introduction}

An ultrasound scan in the midtrimester is now a routine part of antenatal care in most maternity hospitals. As technology improves and skill increases more fetal abnormalities are being recognised in the scans.' The number of amniocenteses performed also continues to rise, mainly as a result of chromosomal screening for high maternal age. These two types of screening procedure can detect serious fetal abnormalities and some parents will opt for termination of the pregnancy. ${ }^{2}$ In the North Western region we offer a service to examine fetuses aborted after a diagnosis of fetal abnormality. Many clinicians use the service but this study does not represent complete ascertainment, though virtually all fetuses aborted after amniocentesis diagnosis in the department are examined. We examined 250 fetuses aborted over five years because of abnormalities detected in the midtrimester and found that the pretermination diagnosis could often be changed or altered substantially in a way which affected genetic counselling. This paper summarises our findings.

\section{Subjects and methods}

Two hundred and fifty fetuses which had been aborted in the midtrimester because of fetal abnormality were received into the regional genetic centre over the five years 1982-7. In 115 cases the diagnosis had been made on amniocentesis samples and a further 133 fetuses had major abnormalities detected by ultrasonography. One fetus was aborted because of maternal phenylketonuria, and one was at high risk of carrying the gene for Huntington's chorea. All referring doctors were asked to give the pretermination diagnosis and to state by which method this had been made. Throughout this report the pretermination diagnosis is taken to be that on which the parents and obstetrician acted when deciding on termination of pregnancy. We request that fetuses are sent as soon after termination as possible in a dry, clean container. Table I lists the routine observations made in each case.

When noting the external appearance we take postmortem changes into account, as these may be mistaken for anomalies and may alter some measure- 
ments appreciably, particularly the occipitofrontal circumference. Medial foot length gives the best correlation with gestational age of all the parameters measured. ${ }^{3}$ Some features such as ear positioning and size of genitalia differ in midtrimester fetuses compared with term neonates and it is important that the examiner is aware of this. Findings on examination may suggest the need for further investigations, and these are listed in table II.

TABLE III - Fetal diagnoses before and after termination and alterations in counselling

\begin{tabular}{|c|c|c|c|c|}
\hline Diagnosis before termination & $\begin{array}{l}\text { No of } \\
\text { cases }\end{array}$ & Diagnosis after termination & $\begin{array}{l}\text { No of } \\
\text { cases }\end{array}$ & $\begin{array}{l}\text { Modified diagnosis } \\
\text { with no change } \\
\text { in risk (C), } \\
\text { increased risk }(\mathrm{C}+), \\
\text { decreased risk }(\mathrm{C}-)\end{array}$ \\
\hline \multirow[t]{6}{*}{ Neural tube defect } & \multirow[t]{6}{*}{71} & $\begin{array}{l}\text { Terminations after ultrasonography } \\
\text { Isolated neural tube defect } \\
\text { Neural tube defect and cleft palate } \\
\text { Neural tube defect and multiple congenital }\end{array}$ & $\begin{array}{r}56 \\
2\end{array}$ & \\
\hline & & $\begin{array}{l}\text { anomalies (unknown cause) } \\
\text { Likely autosomal recessive malformation }\end{array}$ & 5 & $\mathrm{C}+$ \\
\hline & & syndrome & 3 & $\mathrm{C}+$ \\
\hline & & Autosomal recessive cystic hygroma' & 1 & $\mathrm{C}+$ \\
\hline & & 45, $X$ karyotype & 3 & C- \\
\hline & & Early amnion rupture & 1 & C- \\
\hline \multirow{4}{*}{$\begin{array}{l}\text { Structural brain defect } \\
\text { (hydrocephalus ( } 5 \text { cases), } \\
\text { absent corpus callosum (1), } \\
\text { odd shaped head (2), } \\
\text { abnormal ventricles (1), } \\
\text { microcephaly (1)) }\end{array}$} & \multirow[t]{4}{*}{10} & Isolated defect confirmed & 5 & \\
\hline & & $\begin{array}{l}\text { Early amnion rupture } \\
\text { Hydrolethalus syndrome }\end{array}$ & $\begin{array}{l}2 \\
1\end{array}$ & $\begin{array}{l}\mathrm{C}- \\
\mathrm{C}+\end{array}$ \\
\hline & & Meckel-Gruber syndrome? & $i$ & $\mathrm{C}+$ \\
\hline & & Cebocephaly & 1 & $\mathrm{C}+$ \\
\hline \multirow[t]{8}{*}{ Abdominal wall defect } & \multirow[t]{8}{*}{11} & Gastroschisis & 4 & \\
\hline & & Exomphalos & i & \\
\hline & & Exomphalos and diaphragmatic hernia & 1 & C \\
\hline & & Exomphalos and de novo $t(Y: 15)$ & 1 & C- \\
\hline & & Early urethral obstruction & 1 & C \\
\hline & & Early urethral obstruction with trisomy 18 & 1 & $\mathrm{C}+$ \\
\hline & & Imperforate anus & 1 & C \\
\hline & & OEIS complex ${ }^{x}$ & 1 & C \\
\hline \multirow[t]{5}{*}{ Fetal hydrops } & \multirow[t]{5}{*}{11} & $45, \mathrm{X}$ & 6 & C- \\
\hline & & Trisomy 21 & 1 & $\mathrm{C}+$ \\
\hline & & Twin/twin transfusion & 1 & $\mathrm{C}-$ \\
\hline & & Short limbed dwarf & 1 & $\mathrm{C}+$ \\
\hline & & No cause identified, $46, \mathrm{XX}$ & 2 & \\
\hline \multirow{5}{*}{$\begin{array}{l}\text { Known syndrome (previous } \\
\text { family history) }\end{array}$} & \multirow[t]{5}{*}{7} & Meckel-Gruber syndrome & 3 & \\
\hline & & Osteogenesis imperfecta type IIB & 1 & \\
\hline & & $\begin{array}{l}\text { Autosomal recessive polycystic kidneys } \\
\text { Autosomal recessive multiple congenital }\end{array}$ & 1 & \\
\hline & & $\begin{array}{l}\text { Autosomairecessive muituple congenital } \\
\text { anomalies syndrome }\end{array}$ & 1 & \\
\hline & & Treacher Collins syndrome ${ }^{\varphi}$ & i & \\
\hline \multirow[t]{2}{*}{ Placental abnormality } & \multirow[t]{2}{*}{4} & Triploidy & 3 & C- \\
\hline & & $\begin{array}{l}\text { Translocation trisomy } 13 \text { with paternal } \\
t(13: 14)\end{array}$ & 1 & $\mathrm{C}+$ \\
\hline Cardiac defect & 1 & $9 \mathrm{p}$ Tetrasomy & 1 & C- \\
\hline \multirow{2}{*}{ Short limbs } & \multirow{2}{*}{2} & Achondrogenesis & 1 & $\mathrm{C}+$ \\
\hline & & Osteogenesis imperfecta type IIB & 1 & $\mathrm{C}+$ \\
\hline Renal agenesis & 2 & Isolated renal agenesis & 2 & \\
\hline \multirow{3}{*}{ Severe growth failure } & \multirow[t]{3}{*}{3} & Triploidy & 1 & $\mathrm{C}+$ \\
\hline & & $\begin{array}{l}\text { Microcephaly and joint contracture } \\
\text { syndrome (likely autosomal recessive) }\end{array}$ & 1 & Ct \\
\hline & & $\begin{array}{l}\text { syndrome (likely autosomal recessive) } \\
\text { No cause identified }\end{array}$ & 1 & $c+$ \\
\hline \multirow[t]{5}{*}{ "Abnormal" } & \multirow[t]{5}{*}{11} & Early amnion rupture & 3 & $\mathrm{C}-$ \\
\hline & & Body stalk anomaly & 3 & $\mathrm{C}-$ \\
\hline & & Early urethral obstruction and trisomy 13 & 1 & $\mathrm{C}+$ \\
\hline & & Renal cystic dysplasia & 3 & $\mathrm{C}+$ \\
\hline & & Multiple congenital anomalies syndrome & 1 & $\mathrm{C}+$ \\
\hline Total & 133 & & 133 & $\begin{array}{l}C=4 \\
C+=25 \\
C-=24\end{array}$ \\
\hline
\end{tabular}

\begin{tabular}{|c|c|c|c|c|}
\hline \multirow{11}{*}{ Chromosome abnormality } & \multicolumn{3}{|c|}{ Terminations after amniocentesis } & \\
\hline & 71 & Trisomy 21 & 39 & \\
\hline & & Trisomy 21 mosaic & 1 & \\
\hline & & Trisomy 13 & 5 & \\
\hline & & Trisomy 18 & 11 & \\
\hline & & Sex chromosome aneuploidy & 5 & \\
\hline & & $69, \mathrm{XXX}$ & 1 & \\
\hline & & Unbalanced translocation & 4 & \\
\hline & & De novo translocation & 3 & \\
\hline & & $+18,+8$ & 1 & \\
\hline & & Mosaic 5p- & 1 & \\
\hline \multirow[t]{6}{*}{ Neural tube defect } & 32 & Anencephaly & 8 & \\
\hline & & Spina bifida & 18 & \\
\hline & & Neural tube defect and abdominal wall & 3 & \\
\hline & & Meckel-Gruber syndrome & 2 & $\mathrm{C}+$ \\
\hline & & Multiple congenital anomalies with maternal & & \\
\hline & & $t(2: 7)$ & 1 & $\mathrm{C}+$ \\
\hline $\begin{array}{l}\text { Male fetus at risk of } \\
\text { Duchenne's disease }\end{array}$ & 6 & Confirmed male & 6 & \\
\hline Male fetus at risk of Becker's & & & & \\
\hline disease & 1 & Confirmed male & 1 & \\
\hline Abdominal wall defect & 4 & Confirmed isolated abdominal wall defect & 4 & \\
\hline$\alpha$ Thalassaemia & 1 & Confirmed & 1 & \\
\hline Total & 115 & & 115 & $\begin{array}{l}\mathrm{C}=0 \\
\mathrm{C}+=3 \\
\mathrm{C}-=0\end{array}$ \\
\hline
\end{tabular}

Samples for chromosome analysis are obtained by a sterile technique and set up in culture immediately. Macerated tissue is unsuitable. We find that placental tissue grows well and can be used to differentiate between karyotypic abnormalities confined to the placenta and those present in both fetus and placenta. If examination of the fetus leads to suspicion of a particular diagnosis the pathologist is alerted to the possibility of associated internal abnormalities. ${ }^{4}$ An immediate report of the examination findings is sent to the referring doctor suggesting any investigations considered necessary on other family members. This is followed by a further report when the necropsy findings become available. A genetic counselling appointment is offered to parents when appropriate and with the consent of the doctors concerned in their care.

\section{Results}

Table III shows the diagnoses before and after in duced abortion of fetuses with abnormalities detected by ultrasonography or amniocentesis and the way in which the refined diagnosis influenced subsequent counselling. For the 133 fetuses diagnosed by ultrasonography the pretermination diagnosis was confirmed in 80 cases and revised in 53. Of those diagnosed by amniocentesis the pretermination diagnosis was confirmed in 112 cases and revised in three. In all 71 cases in which a chromosome abnormality had been diagnosed the pretermination diagnosis was confirmed as correct. The fetus at risk because of maternal phenylketonuria and the fetus at high risk of carrying a gene for Huntington's chorea both had a normal external appearance.

\section{Discussion}

Our results indicate that when fetal abnormality has been detected by scanning the diagnosis can often be refined by post-termination examination in a way which substantially affects counselling. Revised information about the aetiology of the condition, risk of recurrence, and possibility of prenatal diagnosis in subsequent pregnancies may be provided for the parents. Communication of the post-termination diagnosis back to the diagnostic teams is an important aspect of quality control. A further reason for establishing the diagnosis is for psychological benefit to the parents, who having made a difficult decision to end a wanted pregnancy are reassured that there were valid reasons for choosing to do as they did.

A particular diagnostic group to which attention should be drawn is those fetuses with a pretermination diagnosis of neural tube defect on ultrasonography. Of the 71 instances in this series, 15 fetuses had a posttermination diagnosis other than an isolated neural tube defect. The risk of recurrence for the newly diagnosed disorder was as high as one in four in some cases whereas in other cases the risk was much lower than the $4 \%$ currently quoted for neural tube defect in the North Western region. The methods of diagnosing neural tube defects during the study period changed. In the earlier years most fetuses were diagnosed by amniocentesis and measurement of the amniotic fluid $\alpha$ fetoprotein concentration. In the last year most neural tube defects were diagnosed by ultrasonography after the finding of a raised maternal serum $\alpha$ fetoprotein concentration.

A 45,X karyotype was the commonest cause in our series for the appearance of fetal hydrops during the second trimester. These fetuses were so severely hydropic on examination that survival to term would have been unlikely. The finding of a large, hydropic placenta indicated a chromosome abnormality in all cases seen. 
Manchester et al from Denver reported a series of 257 pregnancies which were complicated by suspected fetal abnormality on ultrasonography. ${ }^{1}$ Thirty seven per cent of the infants born had additional anomalies not detected by prenatal ultrasonography, and the authors concluded that prenatal diagnoses based on ultrasonography were remarkably accurate but were insensitive to associated anomalies in individual cases. Our study confirms this, a revised diagnosis being made in $53(40 \%)$ of such cases.

We believe that examination of midtrimester fetuses by a clinical geneticist is a worthwhile service and improves diagnosis, which in turn benefits the diagnostic teams and parental counselling. It is best carried out by a clinician experienced in dysmorphology, used to normal variations in the appearance of fetuses at various stages in gestation, and familiar with rare dysmorphic syndromes. The collaboration of cytogeneticists and paediatric pathologists is important in defining the full extent of the anomalies in order to arrive at the final post-termination diagnosis, on which the parents will base their future reproductive decisions.
We thank Dr T Andrews, regional cytogenetic service, and his staff and Dr A J Barson, department of paediatric pathology, University of Manchester, and his staff for their skilled work and cooperation.

1 Manchester DK, Pretorius DH, Avery C, et al. Accuracy of ultrasound diagnoses in pregnancies complicated by suspected fetal anomalies. Prinal Diagn 1988;8:109-17.

2 Donnai D. The management of the patient having fetal diagnosis. Bullicre's Clin Obstet Gynaecol 1987:1:737-45.

3 Winter RM, Knowles SAS, Bieber FR, Baraitser M. The pathological examination of the infant and examination of the placenta. In: The malforme t examination of the infant and examination of the placenta. In: $7 /$ c

fetus and stillbirth. Chichester: John Wiley and Sons, 1988:40-68

Kelling JW, ed. Place of structured request forms in prenatal pathology. In: Fetal and neonatal pathology. London: Springer Verlag, 1987:3.

5 Bieber FR, Petres RF, Bieber JM, Nance WE. Prenatal detection of a familial nuchal bleb simulating encephalocele. Birth Defects 1979;15:51-61.

6 Salonen R, Herva R, Reijo N. The hydrolethalus syndrome: delincation of it 'new' lethal malformation syndrome based on 28 patients. Clin (ienct 1981;19:321-30.

7 Meckel S, Pessarge E. Encephalocele, polycystic kidnevs and polydacty is an autosomal recessive trait simulating certain other disorders: the Mecket syndrome. Ann Genet 1971:14:97.

8 Carey JC, Greenbaum B, Hall BD. The OEIS complex (omplaticule exstrophy, imperforate anus, spinal defects). Birth Defects 1978;156B:253-63.

9 Jones KL Smith's recognisable paterns of human mulfor, $156 \mathrm{~B}: 25363$. Philadelphia: W B Saunders, 1988:210-1

(Accepted 29 November 1989)

\title{
Microalbuminuria as predictor of increased mortality in elderly people
}

\author{
Else Marie Damsgaard, Anders Frøland, Ole Dan Jørgensen, Carl Erik Mogensen
}

Abstract

Objective-Correlation of the urinary albumin excretion rate and the risk of death among elderly subjects.

Design-216 Subjects aged 60-74 whose urinary albumin excretion rate had been determined were followed up 62-83 months later.

Setting-Municipality of Fredericia, Denmark.

Subjects-223 People who had been selected as control subjects for diabetics found during a systematic screening for diabetes of all people aged 60-74 living in the municipality of Fredericia, Denmark. Of these subjects, 216 had an extensive clinical and biochemical examination within a few weeks of selection.

Main outcome measure-Death.

Results - The median urinary albumin excretion rate was $7.52 \mu \mathrm{g} / \mathrm{min}$. Eight of those with a rate below the median died compared with 23 with a rate equal to or greater than the median $(p=0.0078)$. The median albumin excretion rate in the 31 who died was $15.00 \mu \mathrm{g} / \mathrm{min}$. Cardiovascular disease was the most common cause of death in both groups. A multivariate regression analysis of survival data was performed using the proportional hazards model. Besides albumin excretion rate, male sex, serum creatinine concentration, and hypertension were found to be of prognostic value.

Conclusions-The association between the albumin excretion rate and mortality that has been described in recent years in patients with diabetes mellitus may be present in elderly people in general, even when other known risk factors are taken into account.

Correspondence to: Dr Else Marie Damsgaard, Institute of Clinical Genetics, J B Winsløwsvej 17, 5000 Odense $\mathrm{C}$, Denmark. present when other risk factors such as male sex, age, obesity, ischaemic heart disease, hypertension, smoking, and raised blood lipid concentrations are taken into account. ${ }^{135}$ Microalbuminuria is also associated with hypertension ${ }^{9}$ and increased cardiovascular morbidity in people who are not diabetic. ${ }^{510}$ We followed up a cohort of subjects drawn from the population of Fredericia ${ }^{11}$ who were recruited to serve as controls for a cohort of diabetics aged 60-74 found during population screening. We followed up the subjects who were not diabetic for 62 to 83 months, or to death, and evaluated their urinary albumin excretion and other possible risk factors for death.

\section{Subjects and methods}

From 1 February 1981 to 31 October 1982 all people aged 60-74 living in the municipality of Fredericia, Denmark, were invited to have their blood glucose concentration measured after fasting overnight. The participants were also interviewed about a possible history of diabetes. Details of the sampling procedure and characteristics of those who did not respond have been described. ${ }^{11}$ We invited 5699 people to participate, $5292(92.9 \%)$ of whom accepted. Of these, 236 gave a history of diabetes. All the people screened were numbered consecutively, and for each diabetic subject a control was defined as the person with the nearest following number who was of the same sex and age (within one year) and whose fasting blood glucose concentration was below $7 \cdot 0 \mathrm{mmol} / \mathrm{l}$. Altogether 223 $(94.5 \%)$ controls consented to further examination. Table I gives the age and sex distributions of this control group (the study population) and the corresponding total population of the municipality. All subjects were asked to have an extensive clinical and biochemical examination.

The blood and urine of subjects were sampled not later than three weeks after the initial screening. Venous blood obtained after subjects had fasted was tested for glucose, serum creatinine, triglyceride, total 